Article

\title{
Probing the DNA Reactivity and the Anticancer Properties of a Novel Tubercidin-Pt(II) Complex
}

\author{
Stefano D’Errico ${ }^{1}{ }^{1}$, Andrea Patrizia Falanga ${ }^{2}$, Domenica Capasso ${ }^{1}{ }^{\circ}$, Sonia Di Gaetano ${ }^{3}(\mathbb{D}$, \\ Maria Marzano ${ }^{4}$, Monica Terracciano ${ }^{4}{ }^{(0)}$, Giovanni Nicola Roviello ${ }^{3}{ }^{(\mathbb{D}}$, Gennaro Piccialli ${ }^{4,5}$, \\ Giorgia Oliviero $2,5, *$ (D) and Nicola Borbone ${ }^{4,5}$ (D) \\ 1 CESTEV, University of Naples Federico II, via Tommaso De Amicis, 95, 80145 Napoli, Italy; \\ stefano.derrico@unina.it (S.D.); domenica.capasso@unina.it (D.C.) \\ 2 Dipartimento di Medicina Molecolare e Biotecnologie Mediche, University of Naples Federico II, \\ via Sergio Pansini, 5, 80131 Napoli, Italy; andreapatrizia.falanga@unina.it \\ 3 Istituto di Biostrutture e Bioimmagini, CNR, via Mezzocannone, 16, 80134 Napoli, Italy; \\ digaetan@unina.it (S.D.G.); giroviel@unina.it (G.N.R.) \\ 4 Dipartimento di Farmacia, University of Naples Federico II, via Domenico Montesano, 49, \\ 80131 Napoli, Italy; maria.marzano@unina.it (M.M.); monica.terracciano@unina.it (M.T.); \\ picciall@unina.it (G.P.); nicola.borbone@unina.it (N.B.) \\ 5 ISBE-IT-Candidate National Node of Italy for ISBE, Research Infrastructure for Systems Biology Europe, \\ University of Naples Federico II, via Domenico Montesano, 49, 80131 Napoli, Italy \\ * Correspondence: golivier@unina.it; Tel.: +39-081-679896
}

Received: 21 May 2020; Accepted: 3 July 2020; Published: 4 July 2020

check for updates

\begin{abstract}
Herein, we reported on the synthesis of a novel $\mathrm{Pt}(\mathrm{II})$ neutral complex having as ligand the nucleoside tubercidin, a potent anti-tumor agent extracted from the bacterium Streptomyces Tubercidicus. In detail, the chelation of the metal by a diamine linker installed at C6 purine position of tubercidin assured the introduction of a cisplatin-like unit in the molecular scaffold. The behavior of the synthesized complex with a double-strand DNA model was monitored by CD spectroscopy and compared with that of cisplatin and tubercidin. In addition, the cell viability was evaluated against HeLa, A375 and WM266 human cancer cell lines using the MTT test. Lastly, the results of the apoptotic assay (FITC Annexin V) performed on the HeLa cancer cell line are also reported.
\end{abstract}

Keywords: tubercidin; cisplatin; platinum complexes; nucleosides; cancer; CD spectroscopy; DNA; cell viability assay; apoptosis; ESI-MS stability studies

\section{Introduction}

Cancer represents the second most frequent cause of death worldwide, particularly in rich countries where it reaps victims just like cardiovascular diseases. Considering that cardiovascular diseases are decreasing thanks to the availability of better treatments and prevention, cancer mortality will most likely become the leading cause of death for adults of middle age in the future. Despite the huge progress achieved in the field of molecular biology with targeted therapies, chemotherapy remains the most effective weapon in the presence of inoperable tumors or metastases [1]. Metallodrugs are a class of chemotherapeutics introduced in the market to improve the life expectancy of cancer patients [2]. The progenitor of such compounds is cisplatin (1, Figure 1) [3], which was approved by the Food and Drug Administration (FDA) in 1978 for the treatment of ovarian and testicular cancers. Cisplatin has a unique mode of action that consists of binding the nuclear DNA of cancer cells, inducing, in the final stage, apoptosis [4]. The severe drawbacks of cisplatin and the acquired resistance of many tumors often force patients to change therapy during the drug regimen. Only a few platinated compounds have been approved by the FDA for the treatment of cancers [5-7]; among them, carboplatin (2) and 
oxaliplatin (3) are characterized by a better tolerated toxicity profile than cisplatin, thanks to the presence of the bidentate dicarboxylate leaving groups, which modulate the reactivity at the metal center [8]. Notwithstanding this favorable achievement, they cannot be considered ideal drugs because of the frequent onset of drug resistance during treatment.<smiles>NP(N)(Cl)(Cl)Cl</smiles>

1<smiles>O=C1OP2(=O)OC(=O)[C@H]3CCCC[C@H]3N[PH]2C1=O</smiles>

3<smiles>N[PH]1(N)OC(=O)C2(CCC2)C(=O)O1</smiles>

2<smiles>Nc1ncnc2c1ccn2[C@@H]1O[C@H](CO)[C@@H](O)[C@H]1O</smiles>

4

Figure 1. The structures of cisplatin (1), carboplatin (2) oxaliplatin (3) and tubercidin (4).

Numerous classes of $\mathrm{Pt}(\mathrm{II})$ compounds have been obtained starting from cisplatin by introducing in the place of the ammonia ligands lipids [9-11], peptides [12,13], sugars [14-16], natural products [17], and some of them have shown interesting anti-proliferative effects. Considering that many anticancer and antiviral drugs currently approved are nucleoside/nucleotide-based [18-21], the study of the ligand properties of modified nucleosides and nucleotides towards $\mathrm{Pt}(\mathrm{II})$ metal centers is an interesting field in the design of novel anti-neoplastic agents [22-29]. In addition, the involvement of protein transporters located on cellular membranes in the molecular recognition and consequent internalization of nucleosides and nucleotides makes them even more attractive for the design of novel metal-based chemotherapeutics [30]. The nucleoside 7-deazapurine riboside, namely tubercidin (4), is a potent antibiotic and anti-tumor agent that is phosphorylated by cellular kinases to the corresponding triphosphate, and, once incorporated into DNA or RNA, could induce damage to nucleic acid functions [31]. In addition, tubercidin takes part in several cellular processes, such as pre-mRNA processing, mitochondrial respiration and purine synthesis [32]. In the last few years, many synthetic efforts have been devoted to the preparation of tubercidin analogues, with the aim to reduce its strong toxicity. Therefore, the molecular scaffold of tubercidin has been altered, by introducing modifications mainly at the $\mathrm{C} 6, \mathrm{C} 7$ and $\mathrm{C} 8$ purine positions. Interestingly, the substitution at the $\mathrm{C} 6$ purine position with alkyl, aryl and heteroaryl substituents has generated analogues endowed with significant biological activities [32]. Among all the tubercidin analogues synthesized so far, the C6 alkylamino derivatives are unprecedented. For the potential biological implications, the presence of two adjacent amine functions on the same alkyl chain is more appealing, as the nucleophilicity of the two nitrogen atoms may be exploited to chelate important bio-metals [33]. Accordingly, we probed the anticancer potential of some platinum(II) complexes carrying the cisplatin-like moiety linked to tubercidin through a $N$-alkyl-amide diamino spacer installed at the C6 purine position (5a-e-(R) and 5a-e-(S), Figure 2) [34,35]. 


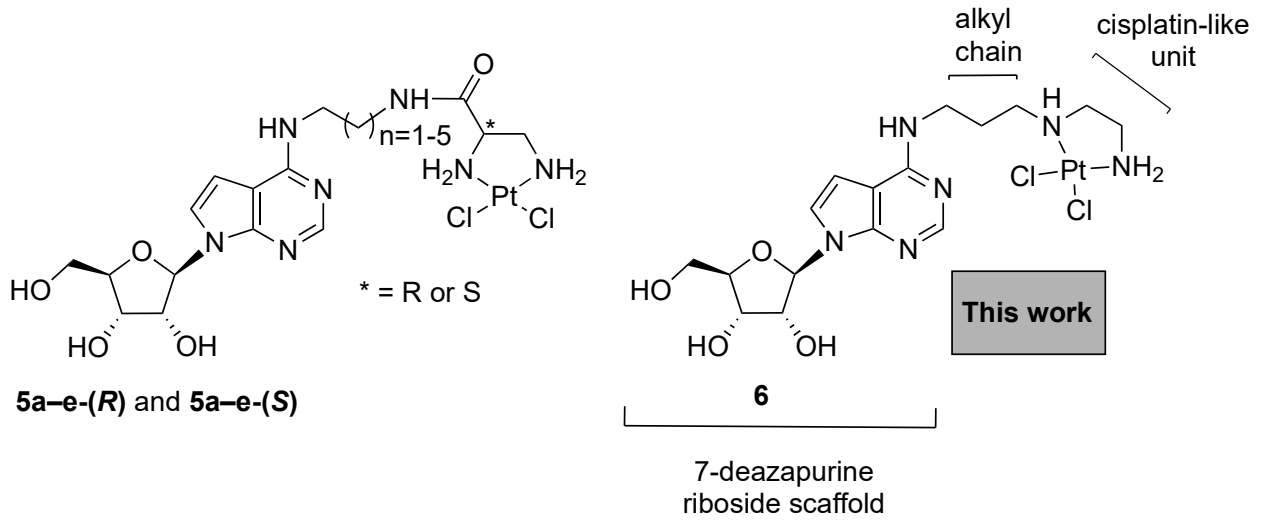

Figure 2. The structures of platinated nucleoside complexes $5 a-e-(R), 5 a-e-(S)$ and $\mathbf{6}$ carrying the 7-deazapurine riboside scaffold.

The lack of the purine N7 atom assured the obtainment of neutral Pt(II) complexes, as a consequence of the sole metalation of the pendant diamine moieties. The compounds 5a-e were screened on two human cancer cell lines and their capability to react with the guanosine $5^{\prime}$-monophosphate, the shortest DNA fragment, was assessed through ${ }^{1} \mathrm{H}-\mathrm{NMR}$ spectroscopy. To assess the effect of a simplified molecular scaffold on the reactivity toward DNA, herein we report on the synthesis of the novel complex 6, obtained by directly connecting the tubercidin scaffold to the cisplatin-like unit [36-38]. The complex $\mathbf{6}$ was tested for its capability to react with a model DNA duplex and the results were compared with those obtained from cisplatin and an equimolar mixture of representative complexes $\mathbf{5 b}-(\boldsymbol{R}) / \mathbf{5 b}-(S)(n=2$, from now $\mathbf{5 b})$. Furthermore, the preliminary in vitro cytotoxic activity of the complex 6 is also reported. We anticipate that the complex 6 reacted more quickly than both cisplatin and the previously synthesized complex $\mathbf{5 b}$ towards the DNA duplex, by inducing conformational distortions to the double helix like those elicited by cisplatin.

\section{Materials and Methods}

\subsection{General Methods}

We obtained all solvents and reagents from commercial sources and used them in the chemical synthesis of the herein-described derivatives without further purification steps. We acquired the ${ }^{1} \mathrm{H}-$ and ${ }^{13} \mathrm{C}$-NMR spectra on a Bruker Avance Neo $400 \mathrm{MHz}$ instrument (Bruker-Biospin, Billerica, MA, USA) using the deuterated solvents $\mathrm{CD}_{3} \mathrm{OD},\left(\mathrm{CD}_{3}\right)_{2} \mathrm{SO}$ and $\mathrm{CDCl}_{3}$. The chemical shifts, given in parts per million ( $\delta)$ and referenced to the residual solvent signal $\left({ }^{1} \mathrm{H}: 3.31 \mathrm{CD}_{2} \mathrm{HOD}, 2.54\left(\mathrm{CD}_{3}\right)\left(\mathrm{CD}_{2} \mathrm{H}\right) \mathrm{SO}\right.$, $\left.7.27 \mathrm{CHCl}_{3} ;{ }^{13} \mathrm{C}: 49.0 \mathrm{CD}_{3} \mathrm{OD}, 40.4\left(\mathrm{CD}_{3}\right)_{2} \mathrm{SO}, 77.0 \mathrm{CDCl}_{3}\right)$, were assigned by 2D-NMR analysis. All acquired NMR spectra were processed by the iNMR software (Nucleomatica, Molfetta, Italy). The UV spectra were measured using a Jasco V-530 UV spectrophotometer (Jasco Europe, Cremella, Italy). The IR spectra were registered on a Jasco FT-IR 430 spectrophotometer (Jasco Europe, Cremella, Italy). The ESI-MS spectra were recorded on an Applied Biosystem mass spectrometer equipped with a triple quadrupole mass analyzer (ThermoFisher, Waltham, MA, USA) and on an LTQ-XL mass spectrometer equipped with an ion-trap (ThermoScientific, Waltham, MA, USA). The HRESI-MS spectra were obtained with a Thermo Orbitrap XL mass spectrometer (Thermo Fisher Scientific, Waltham, MA, USA). Chromatographic separations were performed by using silica gel 60, 70-230 mesh (Merck, Darmstadt, Germany), while the TLC analyses were carried out using $0.2 \mathrm{~mm}$ thick F254 silica gel plates (Merck, Darmstadt, Germany), with TLC spot visualization achieved under UV light $(254 \mathrm{~nm})$. The anionic exchange chromatography was performed on a glass column (10 mm diameter, $100 \mathrm{~mm}$ length) with a fused-in sintered glass-disc (bore of plug $2.5 \mathrm{~mm}$ ) containing an $\mathrm{OH}^{-}$ form resin, 200-400 mesh, loading $=1.2 \mathrm{mmol} / \mathrm{mL}$ (Dowex ${ }^{\circledR}$ 1X8, Sigma-Aldrich, Milan, Italy). The high-performance liquid chromatography (HPLC) was performed on an UP-2075 Plus pump 
equipped with a UV-2075 Plus UV detector (Jasco, Cremella, Italy). The ODNs' HPLC purifications were performed on a Nucleogel ${ }^{\circledR}$ SAX 1000-8 strong anion exchange column (Macherey-Nagel, Duren, Germany) using the following conditions: buffer $\mathrm{A}, 20 \mathrm{mM} \mathrm{NaH}_{2} \mathrm{PO}_{4}$ aqueous solution ( $\mathrm{pH}$ 7.0) containing $20 \%(v / v) \mathrm{CH}_{3} \mathrm{CN}$; buffer $\mathrm{B}, 1 \mathrm{M} \mathrm{NaCl}, 20 \mathrm{mM} \mathrm{NaH}_{2} \mathrm{PO}_{4}$ aqueous solution ( $\left.\mathrm{pH} 7.0\right)$ containing $20 \%(v / v) \mathrm{CH}_{3} \mathrm{CN}$; linear gradient from $0 \%$ to $100 \% \mathrm{~B}$ in $30 \mathrm{~min}$, flow rate of $1.2 \mathrm{~mL} / \mathrm{min}$. The purified ODNs were desalted by molecular exclusion chromatography on Biogel P2 fine (Biorad, Milano, Italy). The HPLC stability experiments were performed using a $5 \mu \mathrm{m}, 250-10 \mathrm{C}-18$ reverse-phase column (Purosphere ${ }^{\circledR}$ STAR, Merck, Darmstadt, Germany) eluted with a linear gradient of $\mathrm{MeOH}$ in $\mathrm{H}_{2} \mathrm{O}$ $(0-100 \%)$ with a flow rate of $2.0 \mathrm{~mL} / \mathrm{min}$.

Human adenocarcinoma (HeLa), human low metastatic melanoma (A375) and human metastatic melanoma (WM266) cell lines were from ATCC (Manassas, VA, USA); normal human dermal fibroblasts (HDF) were from Arterra Biosciences (Napoli, Italy). HeLa, A375 and HDF were grown in DMEM medium supplemented with fetal bovine serum (FBS, 10\%), glutamine $(1 \%)$, penicillin $(100 \mathrm{U} / \mathrm{mL})$ and streptomycin $(100 \mu \mathrm{g} / \mathrm{mL}$, Euroclone, Milano, Italy). WM266 were grown in RPMI supplemented with FBS $(10 \%)$, glutamine $(1 \%)$, penicillin $(100 \mathrm{U} / \mathrm{mL})$ and streptomycin $(100 \mu \mathrm{g} / \mathrm{mL})$ [39]. Cells were maintained at $37^{\circ} \mathrm{C}$ in $5 \% \mathrm{CO}_{2}$ in humidified air.

\subsection{Chemistry}

\subsubsection{Synthesis of Compound $\mathbf{1 1}$}

Compound 7 (300 mg, $0.44 \mathrm{mmol})$, tert-butyl (3-aminopropyl)(2-((tert-butoxycarbonyl)amino)ethyl) carbamate $(8,698 \mathrm{mg}, 2.2 \mathrm{mmol}), \mathrm{Et}_{3} \mathrm{~N}(61 \mu \mathrm{L}, 0.44 \mathrm{mmol})$ were refluxed in $\mathrm{EtOH}(12 \mathrm{~mL})$. After $5 \mathrm{~h}$ (TLC monitoring: PE/ACOEt, 1:1), the system was cooled to r.t. and the solvents removed under reduced pressure. The crude was purified over a silica gel column eluted with PE/AcOEt, 1:1 [40]. The fractions containing the title compound were collected and evaporated to afford pure 11 . White foam (76\% yield). ${ }^{1} \mathrm{H}-\mathrm{NMR}\left(400 \mathrm{MHz} ; \mathrm{CDCl}_{3}\right) \delta 8.30(\mathrm{~s}, 1 \mathrm{H}, 2-\mathrm{H}), 8.14(\mathrm{~d}, J=8.0 \mathrm{~Hz}, 2 \mathrm{H}$, arom.), $7.96(\mathrm{t}, J=9.2 \mathrm{~Hz}, 4 \mathrm{H}$, arom.), 7.56 (ddt, $J=30.4,13.6,7.3 \mathrm{~Hz}, 5 \mathrm{H}$, arom.), 7.37 (q, $J=8.4 \mathrm{~Hz}, 4 \mathrm{H}$, arom.), $7.05(\mathrm{~s}, 1 \mathrm{H}, 8-\mathrm{H})$, 6.69 (complex signal, 2H, 1'-H and NH), 6.11-6.04 (complex signal, $2 \mathrm{H}, 2^{\prime}-\mathrm{H}$ and $\left.3^{\prime}-\mathrm{H}\right), 5.12$ (bs, $0.3 \mathrm{H}$, NHBoc), 4.99 (bs, 0.7H, NHBoc), 4.84 (bd, $\left.J=11.9 \mathrm{~Hz}, 1 \mathrm{H}, 5^{\prime}-\mathrm{H}_{\mathrm{a}}\right), 4.75$ (bs, $\left.1 \mathrm{H}, 4^{\prime}-\mathrm{H}\right), 4.67$ (dd, $J=12.0$, $3.2 \mathrm{~Hz}, 1 \mathrm{H}, 5^{\prime}-\mathrm{H}_{\mathrm{b}}$ ), 3.59 (bd, $\mathrm{J}=4.1 \mathrm{~Hz}, 2 \mathrm{H}, \mathrm{CH}_{2} \mathrm{NH}$ ), 3.42-3.20 (complex signal, $6 \mathrm{H}, 2 \times \mathrm{CH}_{2} \mathrm{NBoc}$ and $\mathrm{CH}_{2} \mathrm{NHBoc}$ ), $1.96-1.78$ (m, 2H, CH ), 1.57-1.35 (complex signal, $\left.18 \mathrm{H}, 2 \times \mathrm{Boc}\right) .{ }^{13} \mathrm{C}-\mathrm{NMR}(101 \mathrm{MHz}$; $\left.\mathrm{CDCl}_{3}\right) \delta 166.1,165.4,165.1,156.3,156.2,156.0,153.2,149.5,133.6,133.4,129.8,129.8,129.7,129.3$, 128.7, 128.5, 128.4, 119.6, 102.5, 89.2, 89.1, 85.5, 80.2, 79.3, 79.0, 73.9, 71.4, 63.8, 46.7, 45.8, 44.4, 39.5, 38.4, 37.4, 29.7, 28.9, 28.3. UV (MeOH) $\lambda_{\max } 275$, sh. 230 nm. ESI-MS m/z $957\left([\mathrm{M}+\mathrm{H}]^{+}, \mathrm{C}_{47} \mathrm{H}_{54} \mathrm{BrN}_{6} \mathrm{O}_{11}\right.$, requires 957$)$.

\subsubsection{Synthesis of Compound 12}

To a solution of compound 11 ( $320 \mathrm{mg}, 0.33 \mathrm{mmol})$ in $20 \mathrm{~mL} \mathrm{MeOH}, \mathrm{NaOAc}(13 \mathrm{mg}, 0.33 \mathrm{mmol})$ and $\mathrm{Pd} / \mathrm{C}(10 \% w / w, 106 \mathrm{mg}, 0.1 \mathrm{mmol})$ were added in a Parr reactor from which the air was removed by insufflating/degassing $\mathrm{H}_{2}$. This apparatus was charged with $\mathrm{H}_{2}$ at a pressure of $10 \mathrm{~atm}$ and the reaction system was allowed to stand for $2 \mathrm{~h}$ at r.t. under stirring (TLC monitoring was achieved by $\mathrm{PE} / \mathrm{AcOEt}, 1: 1$ ). Afterwards, $\mathrm{H}_{2}$ was removed and the mixture was filtered over a Celite 545 pad, subsequently washed with $3 \times 10 \mathrm{~mL} \mathrm{MeOH}$. After solvent evaporation under reduced pressure, the obtained crude was diluted with $30 \mathrm{~mL}$ AcOEt and extracted with saturated brine $(3 \times 30 \mathrm{~mL})$. The separated organic layer, dried on $\mathrm{Na}_{2} \mathrm{SO}_{4}$ and filtered, was concentrated by rotary evaporation furnishing a crude containing compound 12 used for the next reaction without purification. Oil (99\%). ${ }^{1} \mathrm{H}-\mathrm{NMR}\left(400 \mathrm{MHz} ; \mathrm{CDCl}_{3}\right) \delta 8.34$ (s, 1H, 2H, 2-H), 8.14 (d, J = 7.6 Hz, 2H, arom.), 7.96 (dd, $J=14.6$, $7.7 \mathrm{~Hz}, 4 \mathrm{H}$, arom.), 7.61-7.32 (m, 9H, arom.), 7.09 (d, J = 3.5 Hz, 1H, 8-H), $6.74\left(\mathrm{~d}, J=6.0 \mathrm{~Hz}, 1 \mathrm{H}, 1^{\prime}-\mathrm{H}\right)$, 6.65-6.40 (complex signal, 2H, 7-H and NH), 6.19 (apparent t, $J=5.9 \mathrm{~Hz}, 1 \mathrm{H}, 2^{\prime}-\mathrm{H}$ ), 6.11 (apparent t, $\left.J=4.8 \mathrm{~Hz}, 1 \mathrm{H}, 3^{\prime}-\mathrm{H}\right), 5.66$ (bs, $\left.0.3 \mathrm{H}, \mathrm{NHBoc}\right), 5.18$ (bs, $\left.0.7 \mathrm{H}, \mathrm{NHBoc}\right), 4.83(\mathrm{dd}, J=12.0,2.4 \mathrm{~Hz}, 1 \mathrm{H}$, 
$\left.5^{\prime}-\mathrm{H}_{\mathrm{a}}\right), 4.79-4.72\left(\mathrm{~m}, 1 \mathrm{H}, 4^{\prime}-\mathrm{H}\right), 4.67\left(\mathrm{dd}, J=11.9,3.6 \mathrm{~Hz}, 1 \mathrm{H}, 5^{\prime}-\mathrm{H}_{\mathrm{b}}\right), 3.63-3.52\left(\mathrm{~m}, 2 \mathrm{H}, \mathrm{CH}_{2} \mathrm{NH}\right)$, 3.37-3.20 (complex signal, $6 \mathrm{H}, 2 \times \mathrm{CH}_{2} \mathrm{NBoc}$ and $\mathrm{CH}_{2} \mathrm{NHBoc}$ ), 1.95-1.73 (m, $\left.2 \mathrm{H}, \mathrm{CH}_{2}\right), 1.48-1.41$ (complex signal, $18 \mathrm{H}, 2 \times$ Boc). ${ }^{13} \mathrm{C}-\mathrm{NMR}\left(101 \mathrm{MHz} ; \mathrm{CDCl}_{3}\right) \delta$ 166.2, 165.4, 165.1, 156.4, 156.3, 155.9, $152.4,150.3,133.6,133.3,129.8,129.8,129.7,129.4,128.7,128.5,128.4,128.4,120.5,104.2,100.3,85.5,80.4$, 79.9, 79.4, 73.7, 71.6, 64.1, 46.6, 43.9, 39.4, 38.6, 30.3, 28.3. UV (MeOH) $\lambda_{\max } 274 \mathrm{~nm}$, sh. $230 \mathrm{~nm}$. ESI-MS $\mathrm{m} / \mathrm{z} 879\left([\mathrm{M}+\mathrm{H}]^{+}, \mathrm{C}_{47} \mathrm{H}_{55} \mathrm{~N}_{6} \mathrm{O}_{11}\right.$, requires 879).

\subsubsection{Synthesis of Compound 13}

To a solution of compound 12 ( $291 \mathrm{mg}, 0.33 \mathrm{mmol})$ in $3.0 \mathrm{~mL} \mathrm{MeOH}, \mathrm{NaOMe}(89 \mathrm{mg}, 1.6 \mathrm{mmol})$ was added and the obtained system was stirred for $2 \mathrm{~h}$ at r.t. (TLC monitoring was performed by $\mathrm{AcOEt} / \mathrm{MeOH}, 9: 1)$. After solution neutralization with a few drops of glacial acetic acid, solvents were removed under reduced pressure. The resulting crude was diluted with $30 \mathrm{~mL}$ AcOEt and extracted with $3 \times 30 \mathrm{~mL}$ saturated brine. The separated organic layer, dried on $\mathrm{Na}_{2} \mathrm{SO}_{4}$, was filtered and concentrated by rotary evaporation. Crude purification was performed on a silica gel column eluted with increasing amounts of $\mathrm{MeOH}$ in AcOEt (up to 10\%). The fractions containing the title compound were collected and evaporated to afford pure 13. Foam $(80 \%) .{ }^{1} \mathrm{H}-\mathrm{NMR}\left(400 \mathrm{MHz} ; \mathrm{CDCl}_{3}\right) \delta 8.05(\mathrm{~s}, 1 \mathrm{H}$, 2-H), $6.97(\mathrm{~d}, J=3.4 \mathrm{~Hz}, 1 \mathrm{H}, 8-\mathrm{H}), 6.58(\mathrm{bs}, 1 \mathrm{H}, \mathrm{NH}), 6.41(\mathrm{~s}, 1 \mathrm{H}, 7-\mathrm{H}), 5.70\left(\mathrm{~d}, J=7.3 \mathrm{~Hz}, 1 \mathrm{H}, 1^{\prime}-\mathrm{H}\right), 5.07$ (dd, $\left.J=7.3,5.1 \mathrm{~Hz}, 1 \mathrm{H}, 2^{\prime}-\mathrm{H}\right), 4.91$ (bs, $1 \mathrm{H}, \mathrm{NHBoc}$ ), 4.43 (apparent d, $J=5.1 \mathrm{~Hz}, 1 \mathrm{H}, 3^{\prime}-\mathrm{H}$ ), 4.31-4.28 $\left(\mathrm{m}, 1 \mathrm{H}, 4^{\prime}-\mathrm{H}\right), 3.93\left(\mathrm{dd}, J=12.7,1.7 \mathrm{~Hz}, 1 \mathrm{H}, 5^{\prime}-\mathrm{H}_{\mathrm{a}}\right), 3.74\left(\mathrm{dd}, J=12.6,1.4 \mathrm{~Hz}, 1 \mathrm{H}, 5^{\prime}-\mathrm{H}_{\mathrm{b}}\right), 3.62-3.47$ (m, 2H, CH$H_{2} \mathrm{NH}$ ), 3.43-3.20 (complex signal, $6 \mathrm{H}, 2 \times \mathrm{CH}_{2} \mathrm{NBoc}$ and $\mathrm{CH}_{2} \mathrm{NHBoc}$ ), $1.95-1.73(\mathrm{~m}, 2 \mathrm{H}$, $\mathrm{CH}_{2}$ ), 1.54-1.40 (complex signal, $18 \mathrm{H}, 2 \times$ Boc). ${ }^{13} \mathrm{C}-\mathrm{NMR}\left(101 \mathrm{MHz} ; \mathrm{CDCl}_{3}\right) \delta 156.5,156.3,155.9,150.8$, $147.5,124.9,105.6,98.2,92.9,86.7,80.6,79.5,73.0,72.4,63.3,46.6,44.1,39.3,29.7,28.4$. UV (MeOH) $\lambda_{\max }$ $276 \mathrm{~nm}$, sh. $215 \mathrm{~nm}$. ESI-MS m/z $567\left([\mathrm{M}+\mathrm{H}]^{+}, \mathrm{C}_{26} \mathrm{H}_{43} \mathrm{~N}_{6} \mathrm{O}_{8}\right.$, requires 596).

\subsubsection{Synthesis of Compound $\mathbf{1 4}$}

To a solution of compound $13(50 \mathrm{mg}, 0.088 \mathrm{mmol})$ in $\mathrm{CH}_{2} \mathrm{Cl}_{2}(0.5 \mathrm{~mL})$, cooled at $0{ }^{\circ} \mathrm{C}, 0.5 \mathrm{~mL}$ TFA was added in one portion dropwise. The reaction system was warmed to r.t. and allowed to stand for $2 \mathrm{~h}$ under stirring (TLC monitoring was performed by $\mathrm{CH}_{2} \mathrm{Cl}_{2} / \mathrm{MeOH}, 8: 2$ ) [40]. After solvent removal under reduced pressure, the obtained crude was dissolved in water and applied on a glass column containing Dowex- $\mathrm{OH}^{-}$resin (10 equiv.). After elution, first with $\mathrm{H}_{2} \mathrm{O}$ and then with $\mathrm{MeOH}$, we collected the fractions containing compound 14 and removed solvents under reduced pressure. Oil (99\%). ${ }^{1} \mathrm{H}-\mathrm{NMR}\left(400 \mathrm{MHz} ; \mathrm{CD}_{3} \mathrm{OD}\right) \delta 8.10(\mathrm{~s}, 1 \mathrm{H}, 2-\mathrm{H}), 7.25(\mathrm{~d}, J=3.7 \mathrm{~Hz}, 1 \mathrm{H}, 8-\mathrm{H}), 6.56(\mathrm{~d}, J=3.6 \mathrm{~Hz}$, $1 \mathrm{H}, 7-\mathrm{H}), 5.95\left(\mathrm{~d}, J=6.6 \mathrm{~Hz}, 1 \mathrm{H}, 1^{\prime}-\mathrm{H}\right), 4.66\left(\mathrm{dd}, J=6.4,5.4 \mathrm{~Hz}, 1 \mathrm{H}, 2^{\prime}-\mathrm{H}\right), 4.26(\mathrm{dd}, J=5.2,2.6 \mathrm{~Hz}, 1 \mathrm{H}$, $\left.3^{\prime}-\mathrm{H}\right), 4.12-4.08\left(\mathrm{~m}, 1 \mathrm{H}, 4^{\prime}-\mathrm{H}\right), 3.84\left(\mathrm{dd}, J=12.4,2.6 \mathrm{~Hz}, 1 \mathrm{H}, 5^{\prime}-\mathrm{H}_{\mathrm{a}}\right), 3.71\left(\mathrm{dd}, J=12.4,2.8 \mathrm{~Hz}, 1 \mathrm{H}, 5^{\prime}-\mathrm{H}_{\mathrm{b}}\right)$, $3.58\left(\mathrm{t}, J=6.8 \mathrm{~Hz}, 2 \mathrm{H}, \mathrm{CH}_{2} \mathrm{NHC}=\mathrm{N}\right), 2.73\left(\mathrm{t}, J=6.1 \mathrm{~Hz}, 2 \mathrm{H}, \mathrm{CH}_{2} \mathrm{NH}_{2}\right), 2.69-2.59$ (complex signal, $4 \mathrm{H}, 2 \times \mathrm{CH}_{2} \mathrm{NH}$ ), 1.86 (quintet, $\left.J=7.0 \mathrm{~Hz}, 2 \mathrm{H}, \mathrm{CH}_{2}\right) .{ }^{13} \mathrm{C}-\mathrm{NMR}\left(101 \mathrm{MHz} ; \mathrm{CD}_{3} \mathrm{OD}\right) \delta$ 158.1, 152.0, 149.7, 124.6, 105.9, 100.0, 91.6, 87.3, 75.3, 72.7, 63.7, 52.7, 47.9, 41.8, 39.6, 30.5. UV (MeOH) $\lambda_{\max } 276 \mathrm{~nm}$. ESI-MS $m / z 367\left([\mathrm{M}+\mathrm{H}]^{+}, \mathrm{C}_{16} \mathrm{H}_{27} \mathrm{~N}_{6} \mathrm{O}_{4}\right.$, requires 367).

\subsubsection{Synthesis of Complex 6}

Compound 14 (32 mg, $0.088 \mathrm{mmol})$ was dissolved in $1.5 \mathrm{~mL}$ of a $\mathrm{H}_{2} \mathrm{O} / \mathrm{MeOH}(1: 1, v / v)$ solution; $\mathrm{K}_{2} \mathrm{PtCl}_{4}(36 \mathrm{mg}, 0.088 \mathrm{mmol})$ was added and the solution was stirred in the dark at r.t. for $16 \mathrm{~h}$. The precipitate 6 was collected by filtration, washed sequentially with $\mathrm{H}_{2} \mathrm{O}, \mathrm{MeOH}, \mathrm{Et}_{2} \mathrm{O}$ and then dried. Amorphous pale yellow solid (60\%). ${ }^{1} \mathrm{H}-\mathrm{NMR}\left(400 \mathrm{MHz}\right.$; DMSO- $\left.d_{6}\right) \delta 8.18(\mathrm{~s}, 1 \mathrm{H}, 2-\mathrm{H}), 7.71$ $(\mathrm{bt}, J=5.4 \mathrm{~Hz}, 1 \mathrm{H}, \mathrm{NHC}=\mathrm{N}), 7.39(\mathrm{~d}, J=3.4 \mathrm{~Hz}, 1 \mathrm{H}, 8-\mathrm{H}), 7.04(\mathrm{bs}, 1 \mathrm{H}, \mathrm{NH}), 6.66(\mathrm{~d}, J=3.6 \mathrm{~Hz}, 1 \mathrm{H}$, 7-H), $6.22\left(\mathrm{bs}, 2 \mathrm{H}, \mathrm{NH}_{2}\right), 6.03\left(\mathrm{~d}, J=6.3 \mathrm{~Hz}, 1 \mathrm{H}, 1^{\prime}-\mathrm{H}\right), 5.33\left(\mathrm{bt}, J=4.8 \mathrm{~Hz}, 1 \mathrm{H}, 5^{\prime}-\mathrm{OH}\right), 5.29(\mathrm{~d}, J=6.5 \mathrm{~Hz}$ $\left.1 \mathrm{H}, 2^{\prime}-\mathrm{OH}\right), 5.16\left(\mathrm{~d}, J=4.7 \mathrm{~Hz}, 1 \mathrm{H}, 3^{\prime}-\mathrm{OH}\right), 4.48-4.43\left(\mathrm{~m}, 1 \mathrm{H}, 2^{\prime}-\mathrm{H}\right), 4.16-4.10\left(\mathrm{~m}, 1 \mathrm{H}, 3^{\prime}-\mathrm{H}\right), 3.94-3.92$ $\left(\mathrm{m}, 1 \mathrm{H}, 4^{\prime}-\mathrm{H}\right.$ ), 3.68-3.51 (complex signal, $4 \mathrm{H}, 5^{\prime}-\mathrm{H}_{\mathrm{a}, \mathrm{b}}$ and $\mathrm{CH}_{2} \mathrm{C}=\mathrm{N}$ ), 3.36-2.56 (complex signal, 6H, $2 \times \mathrm{CH}_{2} \mathrm{NH}$ and $\left.\mathrm{CH}_{2} \mathrm{NH}_{2}\right), 2.20-1.88\left(\mathrm{~m}, 2 \mathrm{H}, \mathrm{CH}_{2}\right) .{ }^{13} \mathrm{C}-\mathrm{NMR}\left(101 \mathrm{MHz}\right.$; DMSO- $\left.d_{6}\right) \delta 157.0,152.1$, 150.2, 123.1, 104.3, 100.1, 88.4, 86.0, 74.6, 71.6, 62.7, 54.7, 49.9, 46.1, 38.4, 27.9. IR (KBr pellet) 3400, 3233, 
$2927,1610,1563,1463,1367,1303,1250,1094,1048,896,818,726,609,552,420 \mathrm{~cm}^{-1} . \mathrm{UV}\left(\mathrm{H}_{2} \mathrm{O}\right) \lambda_{\max }$ $278 \mathrm{~nm}$, sh. $227 \mathrm{~nm}$. HRESI-MS $m / z 633.1093\left([\mathrm{M}+\mathrm{H}]^{+}, \mathrm{C}_{16} \mathrm{H}_{27} \mathrm{Cl}_{2} \mathrm{~N}_{6} \mathrm{O}_{4} \mathrm{Pt}\right.$, requires 633.1120).

\subsubsection{Preparation of ODNs 15,16}

The complementary ODN sequences 15 and 16 (Table 1) were obtained by solid phase synthesis using $\beta$-cyanoethyl phosphoramidite chemistry on a Expedite 8909 DNA synthesizer. For the syntheses, we used a CPG Universal Support ( $35 \mathrm{mg}, 1.4 \mu \mathrm{mol}$ ) with a $1 \mu \mathrm{mol}$ scale protocol, with the DMT-OFF option. Subsequently, the oligomers were detached from the resin and deprotected by treatment with concentrated aqueous ammonia $\left(\mathrm{T}=55{ }^{\circ} \mathrm{C}, \mathrm{t}=12 \mathrm{~h}\right)$. The combined filtrates and washings were concentrated under reduced pressure. The crudes were dissolved in $\mathrm{H}_{2} \mathrm{O}$, purified by HPLC and desalted. The identity and purity of the ODNs were confirmed by HPLC (data not shown) and ESI-MS analyses (see spectra). The ODN concentration was determined spectrophotometrically at $\lambda=260 \mathrm{~nm}$ and $90{ }^{\circ} \mathrm{C}$, using the molar extinction coefficient $\varepsilon=128.4$ for $\mathbf{1 5}$ and $\varepsilon=96.6 \mathrm{~cm}^{-1} \mathrm{mM}^{-1}$ for $\mathbf{1 6}$, as determined using the Sigma-Aldrich OligoEvaluator ${ }^{\mathrm{TM}}$ web tool (www.oligoevaluator.com).

2.2.7. Preparation of Duplex d15/16 and Incubation with Cisplatin, Tubercidin, Complexes $\mathbf{5 b}$ and $\mathbf{6}$ and Diamine 14

Duplex d15/16 was prepared by mixing ODNs 15 and 16 in a 1:1 ratio at $400 \mu \mathrm{M}$ concentration in $10 \mathrm{mM}$ phosphate buffer solution (PBS) containing $50 \mathrm{mM} \mathrm{NaCl}$ buffer at $\mathrm{pH}=7.0$. The solution was heated at $95^{\circ} \mathrm{C}$ for $5 \mathrm{~min}$, then slowly cooled to r.t over $12 \mathrm{~h}$ (annealing procedure) [41] and equilibrated at $4{ }^{\circ} \mathrm{C}$ for at least $4 \mathrm{~h}$. The resulting solution was finally diluted to $2 \mu \mathrm{M}$ with $10 \mathrm{mM} \mathrm{PBS} / 50 \mathrm{mM}$ $\mathrm{NaCl}$ buffer before $\mathbf{5 b}, \mathbf{6}, \mathbf{1 4}$, cisplatin or tubercidin addition at 1:2 and 1:10 DNA/compound ratio. Stock solutions of $\mathbf{5 b}, \mathbf{6}, \mathbf{1 4}$, cisplatin and tubercidin $(2 \mathrm{mM})$ were freshly prepared by dissolving the solid compounds in a $20 \%$ DMSO containing $0.9 \% \mathrm{NaCl}(154 \mathrm{mM} \mathrm{NaCl})$ solution. After the dissolution, $5 \mu \mathrm{L}$ of the $2 \mathrm{mM}$ and $37.5 \mu \mathrm{L}$ of the $1.3 \mathrm{mM}$ of these samples were taken and rapidly left in contact with the $\mathbf{d 1 5 / 1 6}$ solution, thus being rapidly diluted to the DMSO concentration of $0.04 \%$ and $0.3 \%$ in volume (to be used for the experiments involving 2 and 10 equiv., respectively). The solutions were incubated in the dark at $37^{\circ} \mathrm{C}$ for 24,48 and $72 \mathrm{~h}$ before data acquisition.

\subsection{Spectroscopy}

\subsubsection{Data Acquisition}

CD spectra were acquired on a Jasco 1500 spectropolarimeter equipped with a Jasco PTC-348-WI temperature controller. All spectra were recorded at $37^{\circ} \mathrm{C}$ in the $220-320 \mathrm{~nm}$ range, with a $1 \mathrm{~cm}$ path-length quartz cuvette at the $2 \mu \mathrm{M}$ concentration, and averaged over 5 scans, with the following parameters: $1 \mathrm{~s}$ response time, $100 \mathrm{~nm} \mathrm{~min}{ }^{-1}$ scan rate and $2 \mathrm{~nm}$ bandwidth. For each spectrum, the baseline due to the buffer was subtracted and the resulting spectra were normalized in order to have zero ellipticity at the $360 \mathrm{~nm}$ wavelength [42].

\subsubsection{Melting}

Thermal denaturation experiments were performed by monitoring the $\mathrm{CD}$ values at $278 \mathrm{~nm}$ for d14/15 in the $20-85^{\circ} \mathrm{C}$ temperature range, with a temperature scan rate of $1{ }^{\circ} \mathrm{C} / \mathrm{min}$. The melting temperatures $\left(\mathrm{T}_{1 / 2}\right)$ values have been obtained from the raw data by smoothing with an adaptive filter prior to calculate of the second derivatives using the software Jasco Spectra Manager ${ }^{\mathrm{TM}}$ Suite.

\subsection{Studies of Stability of the Complex 6}

A $0.5 \mathrm{mM}$ solution of the complex 6 was prepared in a $0.9 \% \mathrm{NaCl}$ solution containing a DMSO concentration of $0.5 \%(\mathrm{v} / \mathrm{v})$ and incubated for $72 \mathrm{~h}$ at r.t. in the dark. The extent of degradation of the complex 6 was monitored through HPLC (see General Methods) after 24, 28 and $72 \mathrm{~h}$, setting the UV detector at $\lambda=260 \mathrm{~nm}$. 


\subsection{Biology}

\subsubsection{Cell viability assay}

Cells were plated in 96-well microplates (Corning) at the following densities: 2000 cells/well for WM266 and HDF, 1200 cells/well for HeLa, and 1000 cells/well for A375. After 24 h of incubation, cells were treated by increasing concentrations of synthetized compounds previously solubilized. In detail, the complex 6 and cisplatin were dissolved in $10 \% \mathrm{DMSO} / 0.9 \% \mathrm{NaCl}$, at $2 \mathrm{mM}$ concentration, and then diluted immediately to the final $0.5 \%$ DMSO concentration with the cell growth medium whereas the diamine $\mathbf{1 4}$ and tubercidin were dissolved in $\mathrm{H}_{2} \mathrm{O}$ at $10 \mathrm{mM}$ concentration. Cell viability was examined by using the 3-(4,5-dimethylthiazol-2-yl)-2,5-diphenyltetrazolium bromide (MTT, Sigma Aldrich) assay after $72 \mathrm{~h}$ of treatment. Subsequently, plates were analyzed by a microplate reader (Enspire, Perkin Elmer, USA) at $570 \mathrm{~nm}$. The results, given as percentages of viable cells in respect to the control (vehicle treated cells), are expressed as means ( $\pm \mathrm{SE}$ ) of, at least, three independent experiments (each performed in triplicate). The statistical significance of the differences, evaluated for the anti-proliferative assay, was analyzed by Student's $t$ test, paired, two-sided; a $p<0.05$ was considered significant. The $\mathrm{IC}_{50}$ value of each compound was calculated by GraphPad Prism software.

\subsubsection{Apoptosis Assay}

The apoptosis analysis was performed on HeLa cells seeded at $4 \times 10^{4}$ cells/mL in a 6-well plate. The cells were treated in the absence or presence of $\mathrm{IC}_{50}$ concentration of examined compounds at $37^{\circ} \mathrm{C}$ and apoptosis was analyzed after $72 \mathrm{~h}$ by double staining with annexin V/FITC and propidium iodide (PI) (eBioscience, USA) [43]. The cells undergoing apoptosis were quantified using a flow cytometer equipped with a $488 \mathrm{~nm}$ argon laser (Becton Dickinson, USA) by Cell Quest software. All FACS analyses were performed at least 2 times.

\section{Results and Discussion}

\subsection{Chemistry}

The retrosynthetic analysis (Scheme 1) shows that the platinum complex 6 can be obtained by employing as starting materials the protected 7-bromo-6-chloro-7-deazapurine- $\beta$-D-riboside sugar (7) and tert-butyl (3-aminopropyl)(2-((tert-butoxycarbonyl)amino)ethyl)carbamate (8). The former can be obtained stereoselectively by following the procedure of Seela F. et al. through the coupling of 7-bromo-6-chloro-7-deazapurine (9, Scheme 2) with 1-O-acetyl-2,3,5-tri-O-benzoyl- $\beta$-D-ribofuranose (10) [44], whereas the compound 8 can be readily prepared in three steps in very high yields by following the procedure of Eisenfu, A. et al. [45] that starts from Michael addition of tert-butyl (2-aminoethyl)carbamate to acrylonitrile, followed by Boc protection of the secondary amino group and reduction of the nitrile to a primary amine.
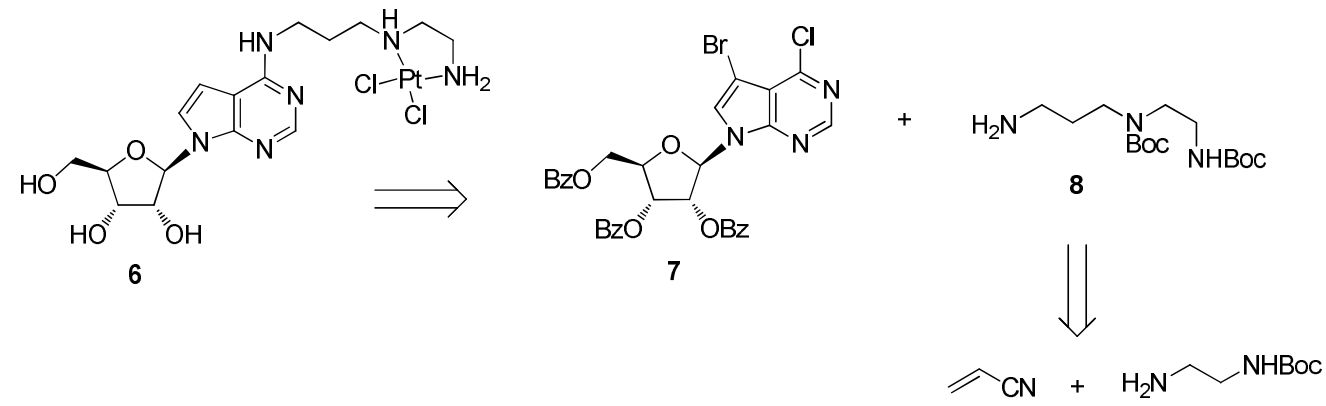

Scheme 1. Retrosynthetic analysis for the preparation of the $\mathrm{Pt}(\mathrm{II})$ complex 6. 
Compound 8 was then reacted with the nucleoside 7 in ethanolic solution under reflux; differently from our previous reports on similar reactions [34,35], compound $\mathbf{1 1}$ did not precipitate after cooling, and the product was isolated only after column chromatography (76\% yield). Next, the C7-Br bond in 11 was hydrogenated in the presence of $\mathrm{H}_{2} / \mathrm{Pd} / \mathrm{C}$ and the crude was directly subjected to the sugar deprotection (Zemplen conditions, $\mathrm{NaOMe} / \mathrm{MeOH}$ ), yielding compound 13 (60\% over two steps). The removal of Boc protecting groups on $\mathbf{1 3}$ was performed with trifluoroacetic acid (TFA) [46] and the crude was then passed over a Dowex- $\mathrm{OH}^{-}$resin to quantitatively recover the free diamine 14.
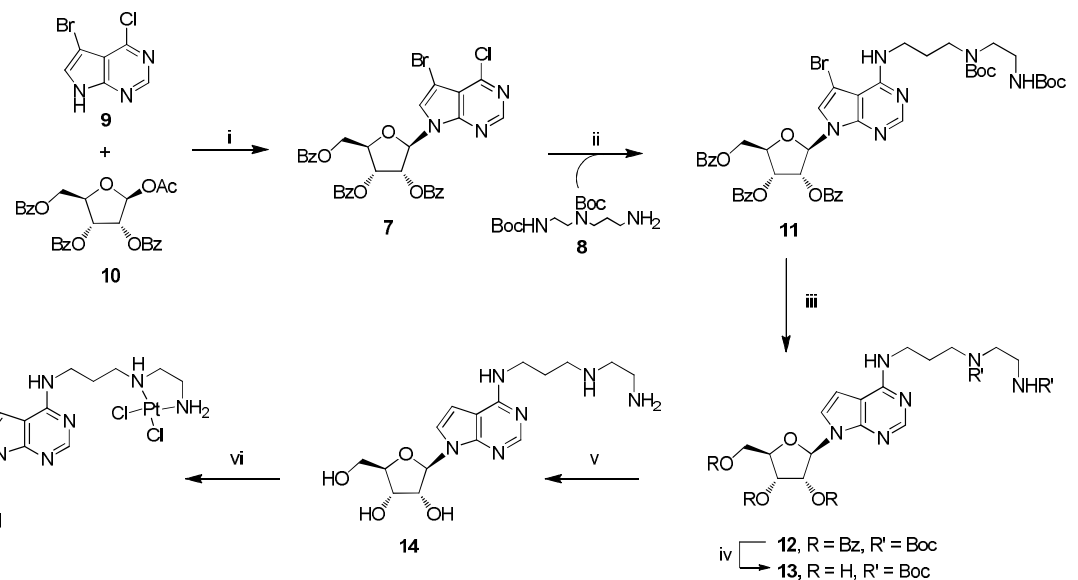

Scheme 2. Reagents and conditions: (i) [44]; (ii) 8, EtOH, 5 h, reflux; (iii) $\mathrm{MeOH}, \mathrm{NaOAc}, \mathrm{H}_{2} / \mathrm{Pd} / \mathrm{C}$, 2 h, r.t.; (iv) $\mathrm{NaOMe}, \mathrm{MeOH}, 2$ h, r.t; (v) (a) Trifluoroacetic acid (TFA) $/ \mathrm{CH}_{2} \mathrm{Cl}_{2}, 1: 1$ (v/v), 2 h, r.t.; (b) Dowex-OH' $\mathrm{OH}^{-}$resin, $\mathrm{H}_{2} \mathrm{O} / \mathrm{MeOH}$; (vi) $\mathrm{K}_{2} \mathrm{PtCl}_{4}, \mathrm{H}_{2} \mathrm{O} / \mathrm{MeOH}$ 1:1, 16 h, r.t., in the dark.

The latter was then reacted with $\mathrm{K}_{2} \mathrm{PtCl}_{4}$, affording the platinum complex 6 as a pale-yellow solid that was isolated by filtration in a $60 \%$ yield. The structures of all intermediates and of platinum complex 6 were determined by NMR and ESI-MS analyses. In detail, the platination of the diamino ethane moiety in the complex 6 was confirmed by the downfield shift of the ${ }^{13} \mathrm{C}$ resonances of $\mathrm{CH}_{2} \mathrm{NH}_{2}$ $(\Delta \delta \approx 5 \mathrm{ppm})$ and $\mathrm{CH}_{2} \mathrm{NH}(\Delta \delta \approx 3 \mathrm{ppm}$ each) compared with the same signals displayed by the diamine 14. Conversely, the platination of $\mathrm{C} 6 \mathrm{NH}, \mathrm{N} 1$ and N3 nitrogen atoms could be excluded, as no significative differences between the chemical shift of carbons belonging to the purine rings of the two compounds were observed [47]. In the HRESI-MS(+) spectrum of complex 6, the base peak corresponded to the protonated bis-chlorinated species; in addition, traces of the fragment ion $[\mathrm{M}-\mathrm{Cl}]^{+}(m / z=596.1347)$ were also detected.

\subsection{Study of the Interaction of the Platinum Complex $\mathbf{6}$ with the Model Duplex DNA d15/16 through CD Spectroscopy}

It is widely accepted that the target of cisplatin is the nuclear DNA and the apoptotic effects are induced by the formation of stable covalent adducts with adjacent guanines located essentially on the same strand [4]. Accordingly, we monitored, through CD spectroscopy, the interaction of the complex 6, the diamine 14, tubercidin and cisplatin with a model duplex DNA having three "GG" boxes (d15/16, Table 1).

Table 1. The oligodeoxynucleotides (ODNs) 15 and 16 used in this study to form the model duplex DNA d15/16.

\begin{tabular}{cc}
\hline ODN & Sequence \\
\hline $\mathbf{1 5}$ & $\mathrm{d}\left(5^{\prime}\right.$-GGAGACCAGAGG-3') \\
\hline $\mathbf{1 6}$ & $\mathrm{d}\left(5^{\prime}\right.$-CCTCTGGTCTCC-3' $)$ \\
\hline $\mathrm{d} 15 / \mathbf{1 6}$ & $\mathrm{d}\left(5^{\prime}\right.$-GGAGACCAGAGG-3') \\
$\mathrm{d}\left(3^{\prime}-\right.$ CCTCTGGTCTCC-5' $)$ \\
\hline
\end{tabular}


In addition, we also monitored the DNA reactivity of the complex $5 b(n=2)$, which shares the alkyl chain length separating the nucleoside scaffold from the cisplatin-like unit with the complex 6 . The DNA duplex d15/16, reported in the literature for the study of novel $\mathrm{Pt}(\mathrm{II})$ complexes [48,49], was obtained by hybridizing equimolar amounts of oligodeoxynucleotides (ODNs) 15 and 16. In parallel experiments, the complexes $5 \mathrm{~b}$ and $\mathbf{6}$, the diamine $\mathbf{1 3}$, tubercidin and cisplatin were incubated in two and ten equiv. excess $[48,49]$ with respect to the duplex $\mathbf{d 1 5 / 1 6}$ and the CD spectra of the resulting mixtures were acquired after 24, 48 and $72 \mathrm{~h}$ of incubation. The CD spectrum of the d15/16 dissolved in $10 \mathrm{mM}$ $\mathrm{PBS} / 50 \mathrm{mM} \mathrm{NaCl}$ ( $\mathrm{pH}=7.0$ ) showed a negative band at $239 \mathrm{~nm}$ due to the characteristic helicity of the right-handed $B$ form and a positive band at $273 \mathrm{~nm}$, indicative of base-stacking (Figure 3) [22,50]. In the presence of two equiv. of $5 \mathbf{b}, \mathbf{6}, \mathbf{1 4}$, tubercidin and cisplatin, no significant differences in the CD spectrum of $\mathbf{d 1 5 / 1 6}$ were found at all time points (Figure S17, Supplementary Material). Conversely, by increasing the ratio from two to ten equiv., relevant conformational changes were observed after incubation of $\mathbf{d 1 5} / \mathbf{1 6}$ with the platinated complexes $\mathbf{5 b}$ and $\mathbf{6}$ and cisplatin (Figure 3). In detail, all complexes induced a disruption of the B-DNA double helix, as evidenced by a reduction of the $273 \mathrm{~nm}$ band together with hypsochromic and bathochromic shifts of the negative and positive signals, respectively (Tables S1-S3, Supplementary Material).
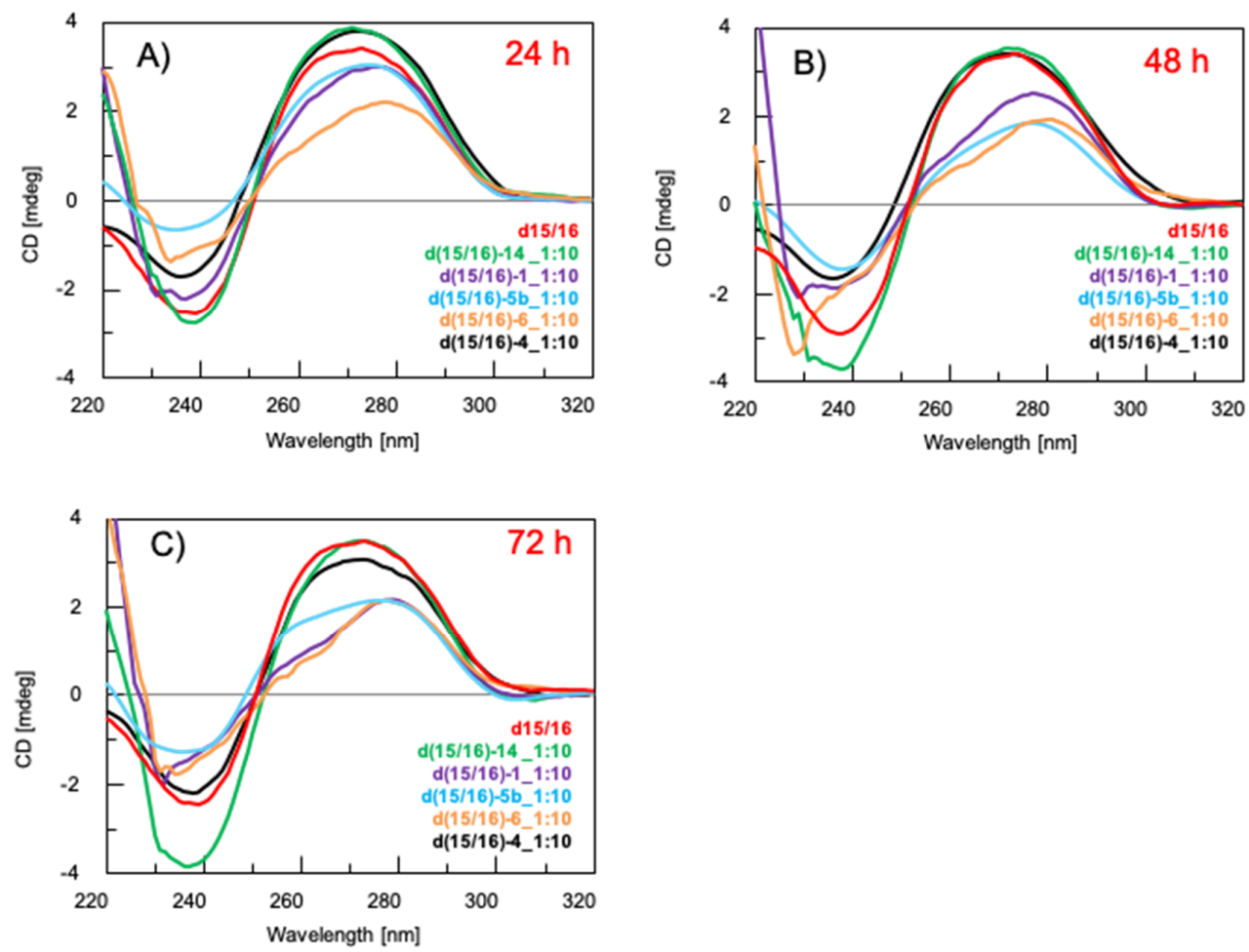

Figure 3. Overlapped CD spectra of $\mathbf{d 1 5} / \mathbf{1 6}$ recorded at $2 \mu \mathrm{M}$ concentration (red line) before and after 24 (panel A), 48 (panel B) and $72 \mathrm{~h}$ (panel C) of incubation with 10 equiv. of $\mathbf{1 4}$ (green line), cisplatin $\mathbf{1}$ (violet line), $5 \mathrm{~b}$ (light blue), 6 (orange line) and tubercidin 4 (black line) at $37^{\circ} \mathrm{C}$. All samples were dissolved in $10 \mathrm{mM}$ PBS/50 mM NaCl-containing buffer at pH 7.0 and the spectra were normalized at $320 \mathrm{~nm}$.

These destabilizing effects are indicative of non-intercalative interactions of the complexes with the double-stranded DNA [50]. The most pronounced changes were elicited by complex 6 after 24 and $48 \mathrm{~h}$ of incubation (Tables S1-S2). In fact, we observed a reduction in maximum intensity of $36 \%$ at $24 \mathrm{~h}$ and $49 \%$ at $48 \mathrm{~h}$, compared to the untreated duplex. In the case of cisplatin, the reduction was $8 \%$ and $26 \%$, whereas for the complex $5 \mathrm{~b}$, the reduction was $6 \%$ and $44 \%$, respectively. Interestingly, the CD profiles obtained after $72 \mathrm{~h}$ of incubation of complex 6 and cisplatin with d15/16 matched, leaving us to speculate that both the complexes could have a similar mechanism of action. The above 
reported CD data unveil the different binding modes of 6 and cisplatin for the studied DNA duplex sequence. We believe that the greater steric hindrance of 6 favors its interaction with the terminal "GG" boxes of the target duplex model at earlier time points, which in turn induces the partial unzip of the double helix as resulting from the observed reduction in the molar ellipticity of the dichroic signals at 239 and $273 \mathrm{~nm}$. Conversely, at $72 \mathrm{~h}$ from the incubation, we did not observe significant variation in the CD profiles of the two complexes, thus indicating that the binding saturation of the "GG" boxes for both cisplatin and 6 occurred. To collect further information on the stoichiometry and stability of the complexes formed by 6 and cisplatin with the d15/16 at 24 and $48 \mathrm{~h}$, we performed CD melting experiments. As expected, the melting curves (Figure S18) evidenced the loss of the duplex structure, with a gradual reduction in the dichroic signal not accompanied by any appreciable inflection point at all the studied time points. Taking into account the differences in the shape of the CD melting profiles recorded at 24 and $48 \mathrm{~h}$, we hypothesize that 6 is faster than cisplatin in reacting with the three "GG" boxes of the d15/16. In particular, its binding with the terminal "GG" boxes could be responsible for the lower mdeg values at 239 and $273 \mathrm{~nm}$ observed in the CD profiles recorded at 24 and $48 \mathrm{~h}$ [22,50]. Regarding the effects of the incubation of the diamine $\mathbf{1 4}$ and tubercidin with d15/16, only weak increases in the intensity of the positive band at $273 \mathrm{~nm}$ were detected after $24 \mathrm{~h}$; conversely, a more relevant increase in the intensity of the negative band at $245 \mathrm{~nm}$ was observed in the case of the interaction of the duplex with the compound $\mathbf{1 4}$ (Figure 3) at all time points. The latter result is likely a consequence of the greater number of polar interactions that diamine $\mathbf{1 4}$ is able to form with the DNA double helix [51,52]. Lastly, both the diamine $\mathbf{1 4}$ and tubercidin did not appreciably affect the melting profile of $\mathbf{d} \mathbf{1 5} / \mathbf{1 6}$ over the $\mathbf{7 2} \mathrm{h}$ incubation period (Figure S19). This study of interaction of tubercidin with a model DNA duplex through CD spectroscopy is unprecedented and allows us to assert that the DNA is not its biological target.

\subsection{Study of Stability of the Complex 6 Dissolved in Physiological Solution}

The strong biological activity of cisplatin is attributable to the presence of the two reactive chloro ligands around the $\mathrm{Pt}$ atom, that can be replaced by several nucleophiles (water, sulfur-donors) in a biological medium. Studies of the stability of cisplatin, carboplatin and oxaliplatin in physiological conditions were recently reported by Varbanov et al. by using the high performance liquid chromatography-mass spectrometry (HPLC-MS) technique [53] and demonstrated that the nature of ligands around the Pt atom could deeply influence the reactivity of the drugs. As the novel complex 6 is a cisplatin mimic, we evaluated its stability in physiological conditions before testing the cytotoxic properties on tumor cell lines. To this aim, we incubated the complex $6(0.5 \mathrm{mM})$ in a physiological solution $(0.9 \% \mathrm{NaCl})$ with DMSO concentration of $0.5 \%$ for $72 \mathrm{~h}$ at r.t., and monitored its stability at 24 , $48,72 \mathrm{~h}$ through HPLC. The main species eluted from the column were collected, diluted with methanol, and analyzed by ESI-MS in positive mode. After $24 \mathrm{~h}$ incubation, the complex 6 mainly decomposed into two species, with retention times $\left(\mathrm{t}_{\mathrm{R}}\right)$ of 11.1 and $12.3 \mathrm{~min}$. respectively (Figure $\mathrm{S} 20$ ). In the ESI-MS spectrum of the firstly eluted species we detected the ions at $\mathrm{m} / \mathrm{z} 597$ and 561 , both possessing the characteristic Pt isotopic patterns of mono-positive ions. The structure of the ion at $\mathrm{m} / \mathrm{z} 597 \mathrm{was}$ assigned as 17 (Scheme 3), that could derive from the not detected mono- $\mathrm{H}_{2} \mathrm{O}$ complex (18), after a removal of the $\mathrm{H}_{2} \mathrm{O}$ molecule during the ionization stage in the mass spectrometer; whereas the ion at 561 (19) was a fragment, generated by the loss of $\mathrm{HCl}$. In the ESI-MS spectrum of the species eluted later, we detected an ion at $\mathrm{m} / \mathrm{z} 675$, showing the characteristic Pt isotopic pattern of a mono-positive ion. The structure was consistent with that of the species 20, derived from the complex $\mathbf{6}$ after displacement of a $\mathrm{Cl}^{-}$by DMSO [54]. After 48 and $72 \mathrm{~h}$ incubations, the HPLC profiles remained almost unchanged, except for the formation of a species eluted at $t_{R}=9.7 \mathrm{~min}$, whose structure has not been identified. The HPLC experiments carried out demonstrated that: (1) a complete consumption of the complex 6 took place after $24 \mathrm{~h}$ incubation, with the parallel appearance of several compounds, whose amounts changed over the $72 \mathrm{~h}$ incubation period; (2) DMSO does interact with the complex 6 even in a very dilute environment, according to a previous report [55]. 


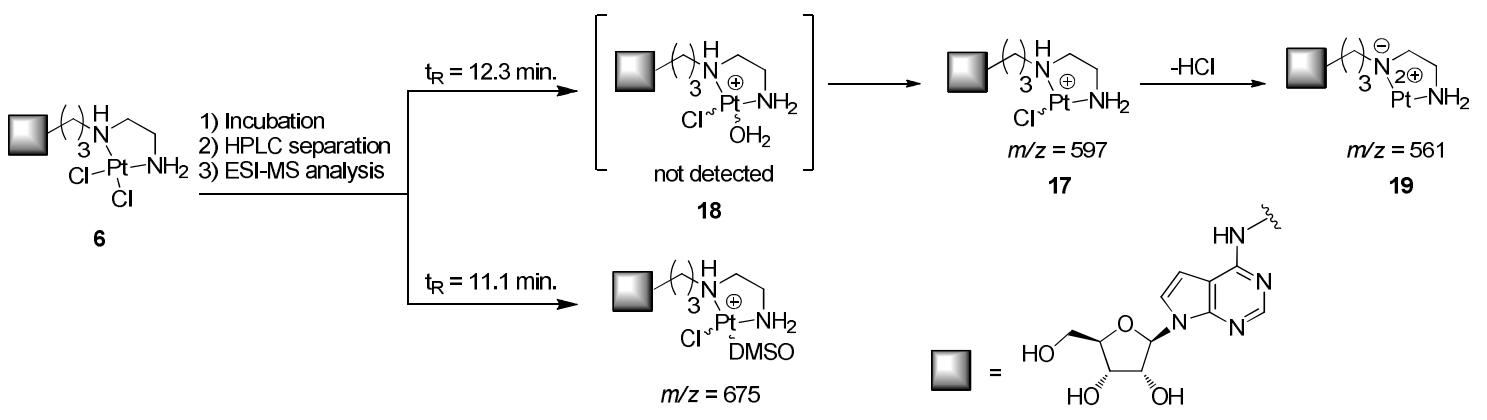

20

Scheme 3. The proposed structures of the main species obtained after incubation of the complex 6 $(0.5 \mathrm{mM})$ in a $0.9 \% \mathrm{NaCl}$ solution containing $0.5 \% \mathrm{DMSO}$ at r.t for $72 \mathrm{~h}$.

\subsection{Biology}

To evaluate the cellular effect upon interaction with the model DNA double helix, biological experiments were carried out. Primarily, cytotoxicity profiles of the platinum complex $\mathbf{6}$ and its diamine precursor 14 were evaluated on three different human tumor cell lines, cervical adenocarcinoma cells (HeLa), low metastatic (A375) and metastatic melanoma cells (WM266), as well as on human dermal fibroblasts (HDF), using the MTT cell viability assay. HDF cells were used as a healthy cellular model to determine the selectivity of action of the examined compounds. For these experiments, cisplatin and tubercidin were used as the positive controls (Table 2 and Figure S21). In detail, cells were incubated for $72 \mathrm{~h}$ in the presence of complexes at increasing concentrations ranging from 5 to $100 \mu \mathrm{M}$ for $\mathbf{6}$ and 14, and from 0.3 to $20 \mu \mathrm{M}$ for cisplatin and from 0.075 to $20 \mu \mathrm{M}$ for tubercidin. Complex 6 and cisplatin were dissolved in $100 \%$ DMSO and immediately diluted with $0.9 \% \mathrm{NaCl}$ aqueous solution to obtain the $2 \mathrm{mM}$ stock solutions, which were diluted with the growth medium at the final concentrations containing less than $0.5 \%$ DMSO $[34,35,50]$. The small amount of DMSO, necessary to completely solubilize the $\mathrm{Pt}(\mathrm{II})$ complex, should not affect its biological activity, in accordance with the recent findings on the combination studies of cisplatin and DMSO on KB-3-1 or DLD-1 tumor cells lines [55]. The resulting dose-response curves, reported in Figure 4, show for complex 6 a concentration-dependent inhibition in all tested cell lines.

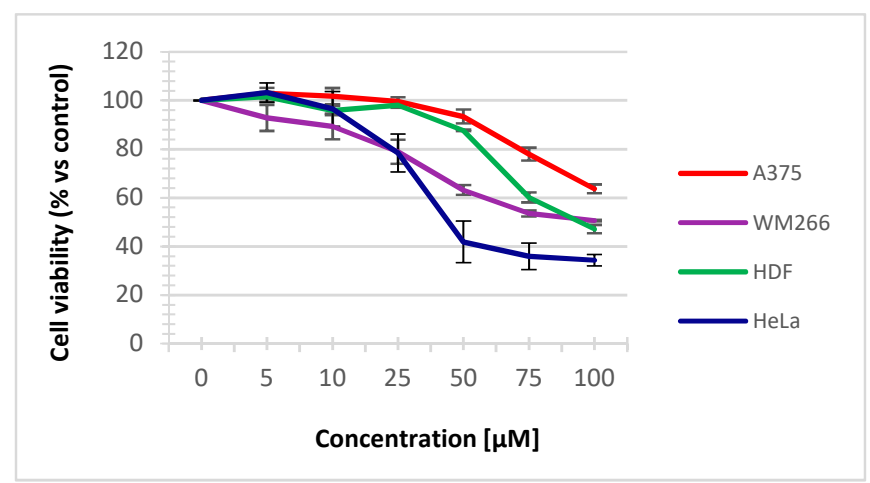

Figure 4. Cell viability assay of complex 6 on HeLa, A375, WM266, and human dermal fibroblasts (HDF) cell lines. The cells were incubated in the presence of compound the indicated concentrations at $37^{\circ} \mathrm{C}$ for $72 \mathrm{~h}$. Cell viability was measured by using the MTT assay. The results are presented as the percentage of viable cells with respect to the control (vehicle treated cells) and are expressed as means \pm SE of at least three independent experiments. A $p \leq 0.01$ was observed from 50 to $100 \mu \mathrm{M}$ for WM266 and HDF, at 75 and $100 \mu \mathrm{M}$ for A375 and HeLa; a $p<0.05$ was observed at 25 and $50 \mu \mathrm{M}$ for HeLa.

In particular, the complex 6 presented a good effect on HeLa cell viability, which decreased to $35 \%$ at the highest tested concentration. Furthermore, the complex 6 proved less active on WM266 and 
only slightly effective on A375 and on healthy HDF, displaying an interesting tumor cell selectivity, the main feature for the development of therapeutic compounds. This selectivity of action was also evident in the evaluation of the $\mathrm{IC}_{50}$ values, as reported in Table 2, that indicated, for the examined complex, an $\mathrm{IC}_{50}$ in the medium micromolar range $(55.1 \mu \mathrm{M})$ on HeLa, a lower effect towards WM266 $\left(\mathrm{IC}_{50}=91.1 \mu \mathrm{M}\right)$ and a low interference in the proliferation of A375 and HDF, showing both $\mathrm{IC}_{50}>100 \mu \mathrm{M}$. The complex 6 proved less active than both cisplatin and tubercidin on all treated cells; however, equally, cisplatin and tubercidin did not display selectivity of action, also with respect to non-tumorigenic cells. Lastly, the diamine precursor 14 was completely inactive on all the screened cell lines (Table 2 and Figure S21).

Table 2. $\mathrm{IC}_{50}$ values obtained after $72 \mathrm{~h}$ incubation with the examined compounds on HeLa, A375, WM266 and HDF cell lines.

\begin{tabular}{ccccc}
\hline Entry & \multicolumn{4}{c}{$\mathrm{IC}_{\mathbf{5 0}}[\boldsymbol{\mu M}]$} \\
\hline Cell lines & HeLa & A375 & WM266 & HDF \\
$\mathbf{6}$ & $55.1 \pm 14.6$ & $>100$ & $91.0 \pm 11.9$ & $>100$ \\
$\mathbf{1 4}$ & $>100$ & $>100$ & $>100$ & $>100$ \\
Cisplatin & $1.8 \pm 0.75$ & $1.3 \pm 0.28$ & $2.4 \pm 0.40$ & $6.3 \pm 1.8$ \\
Tubercidin & $0.11 \pm 0.3$ & $0.085 \pm 0.023$ & $0.076 \pm 0.016$ & $0.47 \pm 0.2$ \\
\hline
\end{tabular}

Apoptosis is a form of programmed cell death, where dead cells are split up into small pieces and are recycled by other cells. In contrast, death through necrosis induces the release of intracellular content and causes inflammation. Therefore, the involvement of the apoptosis process is a desirable feature in the therapeutic action. To evaluate whether the complex 6 was able to induce an apoptosis process, the annexin V/propidium iodine (PI) double staining assay was performed by flow cytometry analysis. Annexin V is an intracellular protein that binds to phosphatidylserine, that, during early apoptosis, trans-locates to the external leaflet of the cell membrane. FITC-labelled Annexin V can then be used to specifically identify apoptotic cells. However, Annexin V binding alone cannot differentiate between apoptotic cells and necrotic. Therefore, PI, at low concentrations, positively stains late-stage apoptotic cells and necrotic cells [56]. So, the necrotic cells will stain with only PI, advanced apoptotic cells with PI and FITC, and early apoptotic cells with only FITC. The assay was performed on HeLa cells, which proved to be the most sensitive cells in the proliferation assay. To this aim, cells were incubated with the complex 6 at $50 \mu \mathrm{M}$ concentration. The results of the experiment show that $13 \%$ of cells treated with this complex were in early apoptosis (Figure 5, panel A) and 5\% in advanced apoptosis (Figure 5, panel B), demonstrating that 6 was able to induce an apoptotic process, according to literature data concerning most of the platinated complexes [57], although to a lesser extent than cisplatin or tubercidin treatments (Figure S22).
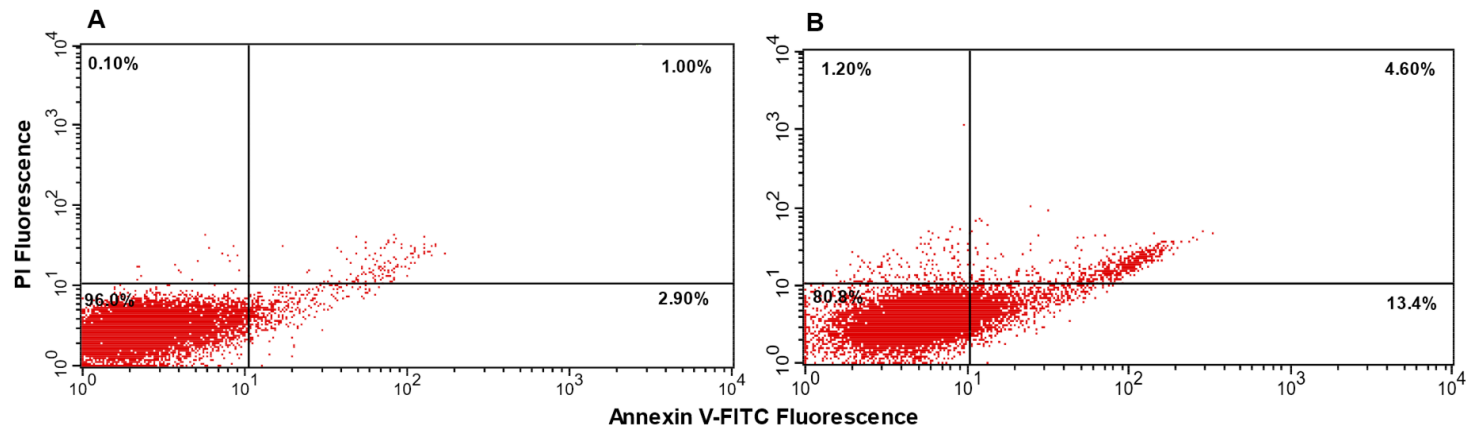

Figure 5. Apoptosis analysis with annexin V-FITC and propidium iodine (PI) double staining on HeLa cells. HeLa cells were seeded at 40,000 cells/well on a 6-well plate and treated with $50 \mu \mathrm{M}$ of complex 6 for 72 h. Panel A: control (vehicle treated cells); Panel B: cells treated with the complex 6. Lower left quadrant: viable cells; upper left: necrotic cells; upper right: advanced apoptotic cells; low right: early apoptotic cells. These pictures are representative of two independent experiments. 


\section{Conclusions}

The conjugation of cisplatin-like units to composite molecular scaffolds produced complexes endowed with interesting cytotoxic properties; accordingly, we focused our attention on the syntheses of $\mathrm{Pt}(\mathrm{II})$ complexes carrying modified nucleosides. With the aim of synthesizing neutral Pt(II) complexes mimicking the cisplatin reactivity, the 7-deazapurine riboside (tubercidin) was tethered at the C6 purine position through the metal-chelating diamino $N$-alkyl-amide and diamino $N$-alkyl linkers, thus obtaining the complexes 5 and $\mathbf{6}$, respectively. Even though the complex $\mathbf{6}$ proved less cytotoxic than cisplatin against the tested cancer cell lines, the results of our CD investigations demonstrate that complex 6 reacted more quickly than cisplatin with the model duplex DNA d15/16 at 24 and $48 \mathrm{~h}$. Given the best propensity of complex 6 to induce conformational changes to the DNA double helix, we hypothesized that its weaker in vitro biological activity could be ascribed either to deactivation processes in intra/extracellular environments, before the $\mathrm{Pt}(\mathrm{II})$ complex can reach its specific target (DNA), or to a poor cellular uptake. Despite the lower cytotoxic activity of complex 6 relative to cisplatin, its greater selectivity toward tumor cells could be exploited in multi-drug therapy approaches. Furthermore, in the light of its selectivity of action and non-cytotoxicity on the normal HDF cell line, studies are underway to encapsulate the $\mathrm{Pt}(\mathrm{II})$ complex 6 in lipophilic macromolecular systems resistant to biological fluids. Lastly, the nucleoside-tethered diamine $\mathbf{1 4}$ could be used for the complexation of other metals useful in anticancer therapy, extending the role of nucleosides in the development of novel potential chemotherapeutics.

Supplementary Materials: The following are available online at http://www.mdpi.com/1999-4923/12/7/627/s1, Figures S1-S13: 1D- and 2D-NMR spectra of compounds 11, 12, 13, 14 and 6, Figure S14: HR ESI-MS(+) spectrum of complex 6, Figure S15: FT IR spectrum of complex 6, Figure S16: ESI-MS(-) spectra of ODNs 15 and 16, Figure S17: CD spectra, Tables S1-S3, Figures S18-S19: CD melting spectra, Figure S20: HPLC stability assay, Figure S21: Cell viability assays, Figure S22: Apoptosis assays.

Author Contributions: S.D., G.O., G.P., and N.B. conceived and designed the experiments; S.D., D.C. and G.P. performed the synthetic experiments; A.P.F., M.M., M.T. and G.N.R. performed the spectroscopic experiments and analyzed the data; D.C. and S.D.G. performed the biological experiments and analyzed the data; S.D., N.B. and G.O. wrote the paper. All authors have read and agreed to the published version of the manuscript.

Funding: This research was funded by Regione Campania-POR Campania FESR 2014/2020 “Combattere la resistenza tumorale: piattaforma integrata multidisciplinare per un approccio tecnologico innovativo alle oncoterapie-Campania Oncoterapie" (Project N. B61G18000470007).

Acknowledgments: The authors are grateful to Annalisa Tito (Arterra Biosciences, Napoli, Italy) for providing HDF cells, to Luisa Cuorvo for providing technical assistance and to Federica Sbordone for her contribution in the purification of the synthesized products. The authors are also grateful to the 'Laboratorio di Analisi Strumentale (LAS)' of the Department of Pharmacy-University of Naples Federico II), for the ESI-MS facilities.

Conflicts of Interest: The authors declare no conflict of interest.

\section{References}

1. Dagenais, G.R.; Leong, D.P.; Rangarajan, S.; Lanas, F.; Lopez-Jaramillo, P.; Gupta, R.; Diaz, R.; Avezum, A.; Oliveira, G.B.F.; Wielgosz, A.; et al. Variations in common diseases, hospital admissions, and deaths in middle-aged adults in 21 countries from five continents (PURE): a prospective cohort study. Lancet 2019, 6736, 1-10. [CrossRef]

2. Ndagi, U.; Mhlongo, N.; Soliman, M.E. Metal complexes in cancer therapy - An update from drug design perspective. Drug Des. Dev. Ther. 2017, 11, 599-616. [CrossRef]

3. Rosenberg, B.; VanCapm, L.; Trosko, J.E.; Mansour, V.H. Platinum Compounds: a New Class of Potent Antitumour Agents. Nature 1969, 222, 385-386. [CrossRef]

4. Ghosh, S. Cisplatin: The First Metal Based Anticancer Drug. Bioorg. Chem. 2019, 88, 102925. [CrossRef]

5. Dilruba, S.; Kalayda, G.V. Platinum-based drugs: past, present and future. Cancer Chemother. Pharmacol. 2016, 77, 1103-1124. [CrossRef]

6. Apps, M.G.; Choi, E.H.Y.; Wheate, N.J. The state-of-play and future of platinum drugs. Endocr. Relat. Cancer 2015, 22, R219-R233. [CrossRef]

7. Mjos, K.D.; Orvig, C. Metallodrugs in medicinal inorganic chemistry. Chem. Rev. 2014, 114, 4540-4563. [CrossRef] 
8. Wang, Z.; Wu, M.; Gou, S. Toward a better understanding of the oxaliplatin mode of action upon the steric hindrance of 1,2-diaminocyclohexane and its analogue. J. Inorg. Biochem. 2016, 157, 1-7. [CrossRef]

9. Sengupta, P.; Basu, S.; Soni, S.; Pandey, A.; Roy, B.; Oh, M.S.; Chin, K.T.; Paraskar, A.S.; Sarangi, S.; Connor, Y.; et al. Cholesterol-tethered platinum II-based supramolecular nanoparticle increases antitumor efficacy and reduces nephrotoxicity. Proc. Natl. Acad. Sci. USA 2012, 109, 11294-11299. [CrossRef]

10. Vhora, I.; Khatri, N.; Desai, J.; Thakkar, H.P. Caprylate-conjugated cisplatin for the development of novel liposomal formulation. AAPS PharmSciTech 2014, 15, 845-857. [CrossRef]

11. Kitteringham, E.; Andriollo, E.; Gandin, V.; Montagner, D.; Griffith, D.M. Synthesis, characterisation and in vitro antitumour potential of novel Pt(II) estrogen linked complexes. Inorg. Chim. Acta 2019, 495, 118944. [CrossRef]

12. Robillard, M.S.; Bacac, M.; Van Den Elst, H.; Flamigni, A.; Van Der Marel, G.A.; Van Boom, J.H.; Reedijk, J. Automated Parallel Solid-Phase Synthesis and Anticancer Screening of a Library of Peptide-Tethered Platinum(II) Complexes. J. Comb. Chem. 2003, 5, 821-825. [CrossRef]

13. Robillard, M.S.; Valentijn, A.R.P.M.; Meeuwenoord, N.J.; Van Der Marel, G.A.; Van Boom, J.H.; Reedijk, J. The First Solid-Phase Synthesis of a Peptide- Tethered Platinum (II) Complex. Angew. Chem. Int. Ed. 2000, 39, 3096-3099. [CrossRef]

14. Cucciolito, M.E.; De Luca Bossa, F.; Esposito, R.; Ferraro, G.; Iadonisi, A.; Petruk, G.; D’Elia, L.; Romanetti, C.; Traboni, S.; Tuzi, A.; et al. C-Glycosylation in platinum-based agents: A viable strategy to improve cytotoxicity and selectivity. Inorg. Chem. Front. 2018, 5, 2921-2933. [CrossRef]

15. Annunziata, A.; Cucciolito, M.E.; Esposito, R.; Imbimbo, P.; Petruk, G.; Ferraro, G.; Pinto, V.; Tuzi, A.; Monti, D.M.; Merlino, A.; et al. A highly efficient and selective antitumor agent based on a glucoconjugated carbene platinum(ii) complex. Dalton Trans. 2019, 48, 7794-7800. [CrossRef]

16. Han, J.; Gao, X.; Liu, R.; Yang, J.; Zhang, M.; Mi, Y.; Shi, Y.; Gao, Q. Design, Synthesis of Novel Platinum(II) Glycoconjugates, and Evaluation of Their Antitumor Effects. Chem. Biol. Drug Des. 2016, 87, 867-877. [CrossRef]

17. Ma, D.-L.; Wu, C.; Cheng, S.-S.; Lee, F.-W.; Han, Q.-B.; Leung, C.-H.; Ma, D.-L.; Wu, C.; Cheng, S.-S.; Lee, F.-W.; et al. Development of Natural Product-Conjugated Metal Complexes as Cancer Therapies. Int. J. Mol. Sci. 2019, 20, 341. [CrossRef]

18. Burke, M.; Borland, K.; Litosh, V. Base-Modified Nucleosides as Chemotherapeutic Agents: Past and Future. Curr. Top. Med. Chem. 2016, 16, 1231-1241. [CrossRef]

19. Berdis, A.J. Inhibiting DNA polymerases as a therapeutic intervention against cancer. Front. Mol. Biosci. 2017, 4, 1-12. [CrossRef]

20. De Clercq, E.; Li, G. Approved antiviral drugs over the past 50 years. Clin. Microbiol. Rev. 2016, 29, 695-747. [CrossRef]

21. Caso, M.F.; D'Alonzo, D.; D’Errico, S.; Palumbo, G.; Guaragna, A. Highly stereoselective synthesis of lamivudine (3TC) and emtricitabine (FTC) by a novel N -glycosidation procedure. Org. Lett. 2015, 17, 2626-2629. [CrossRef] [PubMed]

22. Shahabadi, N.; Abbasi, A.R.; Moshtkob, A.; Hadidi, S. Design, synthesis and DNA interaction studies of new fluorescent platinum complex containing anti-HIV drug didanosine. J. Biomol. Struct. Dyn. 2019, 1-12. [CrossRef] [PubMed]

23. Shahabadi, N.; Fatahi, S.; Maghsudi, M. Synthesis of a new Pt(II) complex containing valganciclovir drug and calf-thymus DNA interaction study using multispectroscopic methods. J. Coord. Chem. 2018, 71, 258-270. [CrossRef]

24. Chen, J.; Li, K.; Swavey, S.; Church, K.M. Synthesis, characterization and DNA binding activity of $\mathrm{PtCl}$ [DMSO][N4[N-3(4-pyridylmethyl)thymidine]]. Inorg. Chim. Acta 2016, 444, 76. [CrossRef]

25. Montagner, D.; Gandin, V.; Marzano, C.; Longato, B. Synthesis, characterization and cytotoxic properties of platinum(II) complexes containing the nucleosides adenosine and cytidine. J. Inorg. Biochem. 2011, 105, 919-926. [CrossRef] [PubMed]

26. Cai, L.; Lim, K.; Ren, S.; Cadena, R.S.; Beck, W.T. Synthesis and in vitro antitumor activity of oligonucleotide-tethered and related platinum complexes. J. Med. Chem. 2001, 44, 2959-2965. [CrossRef] [PubMed]

27. Coluccia, M.; Boccarelli, A.; Cermelli, C.; Portolani, M.; Natile, G. Platinum(II)-Acyclovir Complexes: Synthesis, Antiviral and Antitumour Activity. Met. Based Drugs 1995, 2, 249-256. [CrossRef] [PubMed] 
28. D'Errico, S.; Oliviero, G.; Piccialli, V.; Amato, J.; Borbone, N.; D'Atri, V.; D'Alessio, F.; Di Noto, R.; Ruffo, F.; Salvatore, F.; et al. Solid-phase synthesis and pharmacological evaluation of novel nucleoside-tethered dinuclear platinum(II) complexes. Bioorg. Med. Chem. Lett. 2011, 21, 5835-5838. [CrossRef]

29. D’Errico, S.; Oliviero, G.; Borbone, N.; Piccialli, V.; Pinto, B.; De Falco, F.; Maiuri, M.C.; Carnuccio, R.; Costantino, V.; Nici, F.; et al. Synthesis and pharmacological evaluation of modified adenosines joined to mono-functional platinum moieties. Molecules 2014, 19, 9339-9353. [CrossRef]

30. Pastor-Anglada, M.; Pérez-Torras, S. Emerging roles of nucleoside transporters. Front. Pharmacol. 2018, 9 , 1-8. [CrossRef]

31. Mulamoottil, V.A. Tubercidin and Related Analogues: An Inspiration for 50 years in Drug Discovery. Curr. Org. Chem. 2016, 2, 830-838. [CrossRef]

32. Perlíková, P.; Hocek, M. Pyrrolo[2,3-d]pyrimidine (7-deazapurine) as a privileged scaffold in design of antitumor and antiviral nucleosides. Med. Res. Rev. 2017, 37, 1429-1460. [CrossRef] [PubMed]

33. Piccolo, M.; Misso, G.; Ferraro, M.G.; Riccardi, C.; Capuozzo, A.; Zarone, M.R.; Maione, F.; Trifuoggi, M.; Stiuso, P.; D'Errico, G.; et al. Exploring cellular uptake, accumulation and mechanism of action of a cationic Ru-based nanosystem in human preclinical models of breast cancer. Sci. Rep. 2019, 9, 1-15. [CrossRef] [PubMed]

34. D’Errico, S.; Oliviero, G.; Borbone, N.; Di Gennaro, E.; Zotti, A.I.; Budillon, A.; Cerullo, V.; Nici, F.; Mayol, L.; Piccialli, V.; et al. Synthesis and Evaluation of the Antiproliferative Properties of a Tethered Tubercidin-Platinum(II) Complex. Eur. J. Org. Chem. 2015, 7550-7556. [CrossRef]

35. D’Errico, S.; Borbone, N.; Piccialli, V.; Di Gennaro, E.; Zotti, A.; Budillon, A.; Vitagliano, C.; Piccialli, I.; Oliviero, G. Synthesis and Evaluation of the Antitumor Properties of a Small Collection of Pt II Complexes with 7-Deazaadenosine as Scaffold. Eur. J. Org. Chem. 2017, 4935-4947. [CrossRef]

36. Oliviero, G.; Amato, J.; Borbone, N.; D’Errico, S.; Piccialli, G.; Mayol, L. Synthesis of N-1 and ribose modified inosine analogues on solid support. Tetrahedron Lett. 2007, 48, 397-400. [CrossRef]

37. D'Errico, S.; Piccialli, V.; Oliviero, G.; Borbone, N.; Amato, J.; D’Atri, V.; Piccialli, G. Probing the reactivity of nebularine N1-oxide. A novel approach to C-6 C-substituted purine nucleosides. Tetrahedron 2011, 67, 6138-6144. [CrossRef]

38. D’Errico, S.; Oliviero, G.; Borbone, N.; Amato, J.; Piccialli, V.; Varra, M.; Mayol, L.; Piccialli, G. Solid-phase synthesis of a new diphosphate 5-aminoimidazole-4-carboxamide riboside (AICAR) derivative and studies toward cyclic AICAR diphosphate ribose. Molecules 2011, 16, 8110-8118. [CrossRef]

39. Comegna, D.; Zannetti, A.; Del Gatto, A.; De Paola, I.; Russo, L.; Di Gaetano, S.; Liguoro, A.; Capasso, D.; Saviano, M.; Zaccaro, L. Chemical Modification for Proteolytic Stabilization of the Selective $\alpha v \beta 3$ Integrin RGDechi Peptide: In Vitro and in Vivo Activities on Malignant Melanoma Cells. J. Med. Chem. 2017, 60, 9874-9884. [CrossRef]

40. Oliviero, G.; Amato, J.; Borbone, N.; D’Errico, S.; Piccialli, G.; Bucci, E.; Piccialli, V.; Mayol, L. Synthesis of 4-N-alkyl and ribose-modified AICAR analogues on solid support. Tetrahedron 2008, 64, 6475-6481. [CrossRef]

41. Falanga, A.P.; Cerullo, V.; Marzano, M.; Feola, S.; Oliviero, G.; Piccialli, G.; Borbone, N. Peptide Nucleic Acid-Functionalized Adenoviral Vectors Targeting G-Quadruplexes in the P1 Promoter of Bcl-2 Proto-Oncogene: A New Tool for Gene Modulation in Anticancer Therapy. Bioconjug. Chem. 2019, 30, 572-582. [CrossRef] [PubMed]

42. Amato, F.; Tomaiuolo, R.; Nici, F.; Borbone, N.; Elce, A.; Catalanotti, B.; D’Errico, S.; Morgillo, C.M.; De Rosa, G.; Mayol, L.; et al. Exploitation of a very small peptide nucleic acid as a new inhibitor of miR-509-3p involved in the regulation of cystic fibrosis disease-gene expression. BioMed Res. Int. 2014, 2014, 68-71. [CrossRef] [PubMed]

43. Capasso, D.; Di Gaetano, S.; Celentano, V.; Diana, D.; Festa, L.; Di Stasi, R.; De Rosa, L.; Fattorusso, R.; D'Andrea, L.D. Unveiling a VEGF-mimetic peptide sequence in the IQGAP1 protein. Mol. Biosyst. 2017, 13, 1619-1629. [CrossRef]

44. Seela, F.; Ming, X. 7-Functionalized 7-deazapurine $\beta$-D and $\beta$-L-ribonucleosides related to tubercidin and 7-deazainosine: glycosylation of pyrrolo[2,3-d]pyrimidines with 1-O-acetyl-2,3,5-tri-O-benzoyl- $\beta$-D or $\beta$-L-ribofuranose. Tetrahedron 2007, 63, 9850-9861. [CrossRef]

45. Eisenfu, A.; Arora, P.S.; Sengle, G.; Takaoka, L.R.; Nowick, S.; Famulok, M. A Ribozyme with Michaelase Activity: Synthesis of the Substrate Precursors. Bioorg. Med. Chem. 2003, 11, 235-249. [CrossRef] 
46. D’Errico, S.; Oliviero, G.; Borbone, N.; Amato, J.; D'Alonzo, D.; Piccialli, V.; Mayol, L.; Piccialli, G. A facile synthesis of 5'-Fluoro-5'-deoxyacadesine (5'-F-AICAR): A novel non-phosphorylable AICAR Analogue. Molecules 2012, 17, 13036-13044. [CrossRef] [PubMed]

47. Peng, Y.; Zhang, M.-M.; Chen, Z.-F.; Hu, K.; Liu, Y.-C.; Chen, X.; Liang, H. Synthesis, Characterization, and Interaction with Biomolecules of Platinum(II) Complexes with Shikimic Acid-Based Ligands. Bioinorg. Chem. Appl. 2013, 2013, 565032. [CrossRef]

48. Mügge, C.; Musumeci, D.; Michelucci, E.; Porru, F.; Marzo, T.; Massai, L.; Messori, L.; Weigand, W.; Montesarchio, D. Elucidating the reactivity of $\mathrm{Pt}(\mathrm{II})$ complexes with $(\mathrm{O}, \mathrm{S})$ bidentate ligands towards DNA model systems. J. Inorg. Biochem. 2016, 160, 198-209. [CrossRef]

49. Musumeci, D.; Platella, C.; Riccardi, C.; Merlino, A.; Marzo, T.; Massai, L.; Messori, L.; Montesarchio, D. A first-in-class and a fished out anticancer platinum compound:: $\mathrm{Cis}-[\mathrm{PtCl} 2(\mathrm{NH} 3) 2]$ and cis -[PtI2(NH3)2] compared for their reactivity towards DNA model systems. Dalton Trans. 2016, 45, 8587-8600. [CrossRef]

50. Censi, V.; Caballero, A.B.; Pérez-Hernández, M.; Soto-Cerrato, V.; Korrodi-Gregório, L.; Pérez-Tomás, R.; Dell'Anna, M.M.; Mastrorilli, P.; Gamez, P. DNA-binding and in vitro cytotoxic activity of platinum(II) complexes of curcumin and caffeine. J. Inorg. Biochem. 2019, 198, 110749. [CrossRef]

51. Sirajuddin, M.; Ali, S.; Badshah, A. Drug-DNA interactions and their study by UV-Visible, fluorescence spectroscopies and cyclic voltametry. J. Photochem. Photobiol. B Biol. 2013, 124, 1-19. [CrossRef]

52. Roviello, G.N.; Vicidomini, C.; Costanzo, V.; Roviello, V. Nucleic acid binding and other biomedical properties of artificial oligolysines. Int. J. Nanomed. 2016, 11, 5897-5904. [CrossRef]

53. Varbanov, H.P.; Ortiz, D.; Höfer, D.; Menin, L.; Galanski, M.; Keppler, B.K.; Dyson, P.J. Oxaliplatin reacts with DMSO only in the presence of water. Dalt. Trans. 2017, 46, 8929-8932. [CrossRef] [PubMed]

54. Josephsen, J. Diaminehalogenoplatinum(II) complex reactions with DMSO. Inorg. Chim. Acta 2018, 478, 54-58. [CrossRef]

55. Hall, M.D.; Telma, K.A.; Chang, K.E.; Lee, T.D.; Madigan, J.P.; Lloyd, J.R.; Goldlust, I.S.; Hoeschele, J.D.; Gottesman, M.M. Say no to DMSO: Dimethylsulfoxide inactivates cisplatin, carboplatin, and other platinum complexes. Cancer Res. 2014, 74, 3913-3922. [CrossRef] [PubMed]

56. Boersma, A.W.M.; Nooter, K.; Oostrum, R.G.; Stoter, G. Quantification of apoptotic cells with fluorescein isothiocyanate-labeled annexin $\mathrm{V}$ in Chinese hamster ovary cell cultures treated with cisplatin. Cytometry 1996, 24, 123-130. [CrossRef]

57. Velàzquez, M.; Maldonado, V.; Melendez-Zajgla, J. Cisplatin-induced apoptosis of HeLa cells. Effect of RNA and protein synthesis inhibitors, $\mathrm{Ca}^{2+}$ chelators and zinc. J. Exp. Clin. Cancer Res. 1998, 17, 277-284. [PubMed]

(C) 2020 by the authors. Licensee MDPI, Basel, Switzerland. This article is an open access article distributed under the terms and conditions of the Creative Commons Attribution (CC BY) license (http://creativecommons.org/licenses/by/4.0/). 